\title{
Amoxicillin-Clavulanic Acid
}

National Cancer Institute

\section{Source}

National Cancer Institute. Amoxicillin-Clavulanic Acid. NCI Thesaurus. Code C1481.

A fixed combination of Amoxicillin and Clavulanic Acid, which inhibits beta-lactamase, a bacterial enzyme that inactivates amoxicillin. 